\title{
Bulanık AHP Yöntemi İle Finansal Marka Değerleme Modellerinin Tespiti: Bankacılık Sektöründe Bir Uygulama*
}

\author{
Özlem Nilüfer KARATAŞ ARACI ** \\ İsmail $\mathrm{BEKCI}^{* * *}$
}

\section{$\ddot{O Z E T}$}

Işletmelerin rekabet ortamında varlıklarını sürdürebilmeleri için sadece maddi varlıklarına yatırım yapmaları yeterli olmamaktadır. İsletmelerin sürdürülebilir rekabeti sağlayabilmeleri için farklılaşma yoluna gitmeleri gerekmektedir. Bu farlılaşmayı sağlayacak olan da ancak maddi olmayan duran varlıklarının değerini arttırmakla olacaktır. Günümüzde maddi olmayan duran varlıklar arasında yer alan en önemli varlığın marka olduğu ifade edilmektedir. Bunun farkına varan işletmeler marka değerlerini arttırabilmek için birçok araştırma ve çalışma içine girmişlerdir. Bu bağlamda marka değerinin bu denli önemli hale gelmesinin bir sonucu olarak bu durum, marka değerinin tanımlanması, ölçülmesi ve raporlanması konularını gündeme getirmiş ve dolayısıla bu konuda birçok tartıșa yapılarak marka değerini hesaplamaya yönelik çeșitli modeller ortaya konulmuștur.

Buradan hareketle çalışmanın amacı tartışmaların odak noktasında olan marka değeri belirlenirken hangi modellerin kullanılacağı sorusuna cevap verebilmektir. Çalışmada ülkemizde rekabetin üst seviyeye ulaştı̆̆l bir sektör olan bankacılık sektöründe finansal marka değerleme modellerinden hangisinin kullanılması gerektiği çok kriterli karar verme yöntemlerinden biri olan Bulanık Analitik Hiyerarşi Proses yöntemi kullanılarak tespit edilmeye çalıșllmıştır.

Anahtar Kelimeler: Marka, Marka Değeri, Marka Muhasebesi, Marka Değerleme, Bulanık Analitik Hiyerarşi Süreci, Bankacılık Sektörü.

JEL Sinıflandirması: G21, M41, M49.

\section{Determination Of Financial Brand Valuation Models With Fuzzy AHP} Method: An Application In Banking Sector

\section{ABSTRACT}

The economic conditions, which have been changing over the time, push firms into relentless competitive environment. It is not sufficient to invest in only intangible assets for firms that wish to survive in such environment. Firms need to differentiate and the only way to do this is increasing the value of intangible assets. Nowadays, one of the most important intangible assets is known as brand. The awareness of brand value gives opportunity to improve firms' brand value. The need of doing researches on the topic of brand valuation is took the attention of academicians. Such subjects like the definition, estimation of brand value and reporting come to the fore. Therefore, a lot of discussions have been made on this subject and various models for calculating brand value have been revealed.

Because of the importance of the topic the aim of study is identifying possible models which could give the answer of the best usable models.

In this study, the banking sector, which is the most competitive sector in Turkey, has been chosen, and financial brand valuation models are determined with the help of fuzzy analytical hierarchy process in this sector.

Keywords: Brand, Brand Value, Brand Accounting, Brand Valuation, Fuzzy Analitical Hierarchy Process, Banking Sector.

Jel Classification: G21, M41, M49.

\footnotetext{
* Bu çalışma 'Marka Değerleme Modelleri: BİST Bankacılık Sektöründe Bir Uygulama' doktora tezinden geliştirilerek hazırlanmıștır.

** Yrd. Doç. Dr. Özlem Nilüfer KARATAŞ ARACI, Mehmet Akif Ersoy Üniversitesi, Turizm İşletmeciliği ve Otelcilik Y.O., ozlem_nilufer@yahoo.com.

${ }^{* * *}$ Prof. Dr. İsmail BEKCI, Süleyman Demirel Üniversitesi, İktisadi İdari Bilimler Fakültesi, ismailbekci@gmail.com.
} 


\section{GİRIŞ}

İşletmeler için sürdürülebilir rekabet koşullarında var olmanın yolu maddi olmayan varlıkları elde etmek, yönetmek ve değerlerini artırmaktan geçmektedir. Günümüzde birincil sermaye olarak konumlandırılan markanın değerini bilememek, marka alım satımları sırasında ödenecek bedelin hesaplanmasına yönelik zorluklar yaşanmasına neden olmaktadır. Ayrıca marka değerinin hesaplanması konusunda bir uzlaşıya varılamaması sonucunda UFRS'ye ( Uluslararası Finansal Raporlama Standarları) ve ülkelerin bazı yerel düzenlemelerine göre marka değerinin bilinememesi, işletmelerin bilanço değerlerinin önemini göreceli olarak yitirmesiyle marka varlığının temel finansal tablolarda yer alamamasina sebep olmaktadır.

Markanın işletmeye kattığ tespit edilmesiyle mümkündür. Bu bağlamda, bu ihtiyacı karşılayabilmek için finansal marka, tüketici tabanlı ve karma modeller gibi marka değerleme modelleri geliştirilmiştir. Marka değerleme ile ilgili bu kadar çok modelin olması ve bunların her birinin farklı sonuçlar vermesi, marka değerlerini tespit ettirmek isteyen işletmeleri kararsızlı̆ga sürüklemektedir. Ayrıca markanın finansal bir varlık olarak tüm ekonomik çevreler tarafindan kabul edilmesine rağmen birçok dünya ülkesinde ve ülkemizde mali tablolarda yer alamamasının en temel sebebinin de literatürde yer alan modellerin her birinin farklı sonuçlar vermesi dolayısıyla marka değerinin güvenilir bir şekilde ölçülememesi gösterilmektedir.

Ancak Uluslararası Değerleme Standartları Konseyi (IVSC) ${ }^{1}$, bazı pazarlama örgütleri ve büyük işletmelerin yöneticileri, standart kuruluşları tarafindan marka değerleme ile ilgili standartlar geliştirilerek ortak bir marka değerleme modeli veya sektörlerin özelliklerine göre mevcut marka değerleme modellerinin her sektör için uygulanabilir hale getirilmesi gerekliliğini savunmaktadırlar.

Çalışmada öncelikli hedef, hem en iyi modelin belirlenmesi hem de içerisinde marka değerleme seçim kriterlerinin de yer aldığı bir marka değerleme seçim modelinin oluşturulmasıdır. Bu amaçla "Bulanık Analitik Hiyerarşi Prosesi (BAHP)" kullanılmıştır. Bu yöntemin kullanılmasının sebebi, gerçek hayatta birçok karar verme probleminin çözümünde etkin bir biçimde kullanılmasıdır. BAHP, karar verme sürecindeki belirsizliğin daha kolay üstesinden gelebilmek amacıyla kıyaslama

\footnotetext{
${ }^{1}$ Uluslararası Değerleme Standartları Konseyi (IVSC), değerlem uygulamaları ve değerleme uzmanlığı için küresel standart belirleyici görevi gören, kamu yararına hizmet eden bağımsız, kar amacı gütmeyen bir kuruluştur.
} 
oranlarını bir değer aralığında vermektedir. Bu durum çok kriterli karar verme modelleri arasında BAHP' yi öne çıkarmaktadır.

\section{MARKA VE MARKA DEĞERİ KAVRAMI}

Marka kelimesinin etimolojik kökeni incelendiğinde, İtalyanca "marca" kelimesi karşımıza çıkmaktadır. (Kevin, 2008: 2). Marka kelimesinin Türkçe'ye geçişi bu dildendir. Markanın günümüzdeki anlamıyla kullanılması 19. yüzyılın son çeyreğinden itibaren gerçekleşmiştir. Teknoloji ve iletişimde meydana gelen gelişmelerle birlikte küreselleşen dünyada tüketicilerin, ürünler arasında seçim yaparken bir takım standartlara sahip ürün ve hizmetleri sunan işletmeler, kendi standartlarını ve kimliklerini yansıtacak bir araca ihtiyaç duymuşlardır. Marka kavramı işte tam da bu ihtiyacı karşılayan araç olarak literatürde yerini almıştır.

Yasal tanımına bakılacak olursa 556 Sayılı Markaların Korunması Hakkında Kanun Hükmünde Kararnamenin Uygulanmasına Dair Yönetmeliğin 5. maddesine göre marka; "Bir teşebbüsün mal veya hizmetlerini bir başka teşebbüsün mal veya hizmetlerinden ayırt etmeyi sağlaması koşuluyla, kişi adları dahil, özellikle sözcükler, şekiller, harfler, sayılar, malların biçimi veya ambalajları gibi grafik gösterimi mümkün olan her türlü işaretten oluşabilir” şeklinde tanımlanmıştır ( 556 Sayılı Markaların Korunması Hakkında KHK, Kararname Tarihi: 1995)

Bu tanımlamalar ve marka üzerine yapılan araştırmalar göz önüne alınarak ortak bir marka tanımı yapmak gerekirse, marka; küreselleşmeyle hat safhaya ulaşan acımasız rekabet koşullarında ve marka savaşlarının yaşandığı günümüz dünyasında işletmenin ürettiği ürün ve hizmetleri rakiplerinden farklı kılacak aynı zamanda tüketicinin zihninde farkındalık yaratarak sadakati sağlayacak bir güçtür.

1990'ların başından itibaren akademisyenlerin dikkatini çekmeye başlayan marka değeri kavramı ise pazarlama faaliyetleri ile ortaya çıkan, gelecekteki karları yansitan finansal olmayan piyasaya dayalı maddi olmayan duran varlıkların önemini göstererek kısa ve uzun vadeli pazarlama başarıları arasında köprü kurulması amacıyla ortaya çıkmıştır (Konecnik vd., 2007: 402).

Peter Farquhar'ın (1989), "Managing Brand Equity" adlı makalesi, marka değerine ilişkin kavramların ve yaklaşımların belirlenmesinde ilk çalışmalardan biridir. $\mathrm{Bu}$ çalışmada, özellikle marka değerinin oluşturulmasında, kaliteli ürüne ait olumlu marka değerlendirmelerinin tüketici satın alma davranışını etkileyen marka tutumlarının ve müşterilerle ilişkiler geliştirmek için tutarlı ve sürekli marka imajının önemini vurgulamıştır. Farquhar'ın ardından Baldinger (1990) marka değerini, yöneticilerin ve pazarlama araştırmacılarının odağını taktiklerden, stratejik karar almaya yönlendiren önemli bir firsat olarak kabul ederek, işletmelerin temel stratejisini içeren birer markaya sahip olması gerekliliğinin ve yeni ürün sunumlarında marka yayımının öneminin, marka değerine yönelik çalışmaları arttırdığını vurgulamıştır. 
Marka değeri kavramı üzerinde, literatürde araştırmacılar tarafından bir uzlaşma sağlanamadığı görülmektedir. Ancak bu çalışmalardaki marka değeri tanımlamaları incelendiğinde genel olarak iki temel perspektife dayanan tanımlamalar yapıldığ 1 görülmektedir. Bunlardan birincisi olan finansal perspektif, işletme değerini vurgulayarak marka değerini oluşturan finansal değerin sebeplerini göz önünde bulundurmaktadır. İkincisi olan pazarlama perspektifinde ise tüketicinin marka ile ilgili davranışlarının yarattı̆̆ı değer dikkate alınmaktadır (Haydeé, vd., 1997: 296).

\section{MARKA DEĞERLEME KAVRAMI}

Markaların değer yaratan bir varlık olarak öneminin fark edilmesinden sonra, dünyanın önde gelen işletmeleri marka olgusunun faaliyetleri üzerinde nasıl etkili olduğunu araştırmaya başlamışlardır (Şoğur, 2012: 31). Bu araştırmalar sonucunda, marka değerinin hesaplanması gerekliliği ortaya çıkmıştır.

Marka değeri hesaplamaları önceleri yalnızca işletme birleşmeleri, satın almalar, devretmeler gibi sebeplerle yapılmaktaydı (Gödren, 2010: 16) . Bu duruma en bariz örnek, İngiltere'de Goodman Fielder Wattie (GFW) isimli bir gida şirketinin, aynı sektörde faaliyet gösteren Ranks Hovis McDougall'1 (RHM) ele geçirmek istemesi üzerine, RHM yönetiminin işletmelerinin sahip olduğu markaları değerleterek mali tablolarında göstermesidir. Bu olay literatürde marka değerleme tarihinin de başlangıcı olarak kabul edilmektedir. (Motameni ve Shahrokhi, 1998: 275).

\section{MARKA DEĞERLEME MODELLERİ}

Marka değeri kavramıyla ilgili ilk ihtiyaç finans departmanlarında doğduğu için marka değerinin tespitine yönelik gerçekleştirilen ilk modeller de finans temelli olmuştur (Kaya, 2013: 5). Kurumsal finans uzmanları kolay ve güvenilir bir şekilde elde edilebilecek verilere dayanan ve uygulamada daha rahat kullanılabilecek modeller ile hızlı bir şekilde marka değerini tespit etmeye yönelmişlerdir. Bu yaklaşımı öne süren araştırmacılar, marka değerini bir ürünün marka ismi ile yarattığı nakit akışları olarak açıklamışlardır. ( Deran, vd., 2008: 59-60)

Sonraki yıllarda finansal değerleme modelleri tüketici bakış açısını hiç hesaba katmadıklarından dolayı eleştirilmişılerdir. $\mathrm{Bu}$ eleştirilerin dikkate alınmasıyla ve pazarlama faaliyetlerine yön vermek maksadıyla tüketici eğilim ve algılarını tespit etmek üzere gözlem, anket v.b. yöntemlere dayanan tüketici temelli modeller geliştirilmiştir. Bu modellere verilebilecek örneklerden bazıları Aaker(1991, 1996) ve 
Keller (1993)'in geliştirdikleri modellerdir. Bu modeller marka değerini parasal olarak ortaya koymada yetersiz kalmaktadırlar.

Hem finansal marka değerleme modellerinin hem de tüketici tabanlı marka değerleme modellerinin eksik yönleri olduğunu ifade eden danışmanlık şirketleri ve akademisyenler, markanın hem tüketici boyutunu hem de finansal boyutunu dikkate alarak karma modelleri geliştirip her iki yöntemin eksikliklerini birbiriyle tamamlama yoluna gitmişlerdir. Çalışmada finansal temelli marka değerleme modelleri arasında bir seçim yapılacă̆ından dolayı aşağıda finansal temelli marka dĕ̆erleme modelleri açıklanmıştır.

\subsection{Finansal Temelli Marka Değerleme Modelleri}

Finansal modeller, markanın muhasebeleştirilmesi, marka sahibi işletmenin bir başka işletme tarafından satın alınması veya başka bir işletmeyi satın alması ve franchising gibi durumlarda, markanın finansal değerinin hesaplanması ya da tahmin edilebilmesi amacına yönelik olan modellerdir (Firat ve Badem, 2008: 212). Finansal temelli modelleri dört ana başlık altında toplamak mümkündür.

Maliyete dayalı marka değerleme modelinde; marka bir varlık olarak kabul edilir. İşletmenin sahip olduğu markanın değeri, o marka için katlanılan maliyetlerin toplamı olarak ifade edilmektedir. İki tür hesaplama yönteminden söz etmek mümkündür. Bunlar tarihi maliyet ve ikame maliyet marka değerleme modelleridir. ( Çelik, 2001: 197)

Piyasa değerine dayalı marka değerleme modeli; aynı ürünü üreten piyasadaki diğer markalarla yapılan kıyaslama ile sonuca ulaşma esasına dayanmaktadır. Model, markalar için gerçek bir piyasanın var olduğunu ve bu piyasada emsal alınabilecek işlemler gerçekleştiğini varsaymaktadır (Furat ve Badem, 2008: 212). Bu model çalışmada kullanıldığı için ileriki bölümlerde detaylı olarak açıklanmıştır.

Sermaye Piyasalarına Dayalı Marka Değerleme Modelleri; sermaye piyasalarına dayalı olarak marka değerini hesaplamaktadır. Markası değerlenecek olan işletmenin sermaye piyasalarında faaliyette bulunduğu, işletmenin markaya bağlı stratejilerinin etkilerinin ve marka ile ilgili olumlu ya da olumsuz tüm haberlerin borsaya yansıyacağı ve bunların sonucunda marka değerinin olumlu ya da olumsuz etkileneceği varsayılmaktadır (Wyner, 2004: 6).

Gelire Dayalı Marka Değerleme Modelleri; Bir adı da ekonomik değer yaklaşımı olan model, markanın gelirlere olan katkısını çeşitli teknikler yardımıyla oransal olarak ölçmektedir (Çelik, 2001: 197) . Bu ölçümü yaparken, markadan ekonomik ömrü boyunca kaynaklanması gereken kar ve nakit akımlarının bugünkü değerine indirilmesi yaklaşımına dayanmaktadır (The Ministry of Economy, Trade and Industry The Government of Japan, "The Report of the Commitee on Brand Valuation", 2002: 59). 
Çalışmamız bankacılık sektörü özelinde gerçekleştirilmiştir. Bu sektörde kullanılabilecek finansal marka değerleme modelleri incelendiğinde bazı modellerin birbirine çok benzemesi, bazılarının ise bankacılık sektörüne göre revize edilmesinin mümkün olmaması nedeniyle yukarıda bahsi geçen 19 finansal marka değerleme modelinden 9'u kullanılmıştır, bu modellerden piyasa değeri ile marka değerleme modeli yukarıda diğer modeller ise aşağıda bu detaylı olarak açıklanmıştır.

\subsubsection{Tarihi Maliyet Marka Değerleme Modeli}

$\mathrm{Bu}$ modelde markanın değeri, markayı satın alma veya markayı yaratmak ve markanın sürdürülebilirliğini sağlamak için katlanılan tüm maliyetlerin toplamıdır (Farquhar, vd., 1992: 20). Genelde tazminat hesaplamaları ile bazı yasal durumlarda uygulanmakta olan tarihi maliyet modeli formulize edilecek olursa; (Dutta ve Gupta, 2011: 503)

MD = MGM + MPDM + MPM şeklinde ifade edilebilir. Formülde;

MD: Marka Değeri, MGM: Marka Geliştirme Maliyetleri, MPDM: Marka Pazarlama ve Dağıtım Maliyeti, MPM: Marka Promosyon Maliyetlerini, ifade etmektedir.

\subsection{2. İkame Maliyet Marka Değerleme Modeli}

Tarihi maliyet modelinin sorunlarını bertaraf etmek için geliştirilen bir hesaplama modelidir. Modelin esası aynı markanın tekrar oluşturmak istenildiğinde yapılan toplam maliyettir (Farquhar, vd., 1992: 21) . Diğer bir değişle satın alınamayacak bir markayı referans kabul ederek bu markayı yaratma maliyetini hesaplamaktır. Bu hesaplama yapılırken referans markanın farkındalığı, pazar payları, dağıtım ağları, imajı, liderliği, uluslararasılı̆̆ı gibi özelliklerin aynı marka değerini elde edebilecek başka bir marka yaratmak için ne kadarlık bir harcamanın ne sürede yapılması gerektiğinin belirlenmesini esas alınır (Şoğur, 2012: 38 ) .

\subsubsection{Simon \& Sullivan Marka Değerleme Modeli}

Sermaye piyasalarına dayalı olarak marka değerini ölçme modelinin temellerini Simon \& Sullivan birlikte atmışlardır. Model, genel olarak marka değerini gelecekte elde edilecek, sadece markaya dayandırılabilen gelirlerin bugünkü değeri olarak tanımlamıştır. Modelde, sermaye piyasaların etkin olduğunu ve işletmenin piyasa değerinin, işletmenin sahip olduğu tüm maddi ve maddi olmayan varlıkların gelecekte elde edeceği gelirleri yansıttığı varsayılmaktadır (Simon ve Sullivan, 1993: 28-32). 


\subsubsection{Fiyat Primi Modeli}

Piyasada herkes tarafindan tanınmış bir markaya sahip ürün ile markasız ya da tanınmayan bir ürün arasında, markası bilinen ürün lehine fiyat farklılaştırmasının olacağı varsayımına dayanmaktadır (Feldwick, 1996: 85). Tüketicinin markalı bir ürüne, markasız ürüne kıyasla daha yüksek bir fiyat ödemeye razı olacağı kabul edilmektedir. Model gelire dayalı marka değerleme modelleri arasında en çok rağbet görendir (The Ministry of Economy, Trade and Industry The Government of Japan,2002: 60 ).

\subsubsection{Royaltilerden Kurtulma Modeli}

Gelir yaklaşımları içerisinde en çok kullanılan modellerden biridir (Contractor, 2001: 195). Model, markaya sahip olan bir işletmenin markayı başka bir işletmeye lisans vermesi varsayımına dayanmaktadır ( Haxthausen, 2009: 22). Royalti bedeli; bir lisans veya ticari marka sahibinin sahip olduğu hakları bir başkasına devretmesi karşılığ 1 aldığ 1 bedeldir (www.muhasebeturk.com.tr Erişim Tarihi:21/12/2013). İşletmenin elinde bulundurduğu hakları teorik olarak başkasına devrettiği varsayılarak teorik bir fiyat oluşturulmaktadır ( Kaya, 2013: 10).

\subsubsection{Hedonik Model}

Model 1995 yılında Sander tarafından geliştirilmiştir. Modelin dayandığg teori; ürün fiyatının ürün özellikleri cinsinden açıklamaya çalışılmasıdır. Model, ürün özellikleri fiyat arasında güçlü bir ilişki olduğunu savunmaktadır. Modeldeki asıl amaç, markalı ürünlerin fiyatlarının ne kadarlık kısmının markadan kaynaklandığını tespit etmektir. Bunun için öncelikle hedonik fiyat fonksiyonu kurulmalıdır ( Zimmermann, vd., 2001: 37). Bu fonksiyon varlığın fiyatına etki eden her karakteristiğin (ürün özelliliğinin) sayısal karşılığını ortaya koymaktadır. Böylelikle analiz marka dahil, her bir bireysel ürün karakteristiğinin belirlenmesi ve yarıştırılmasını sağlamaktadır. Hedonik fiyat fonksiyonu şu şekilde kurulabilmektedir;

$\mathbf{y}=\beta_{0}+\beta_{1} * x_{1}+\beta_{2} * x_{2}+\ldots . .+\beta_{n} * x_{n}+\epsilon$

$\mathbf{y}=$ Varlığın fiyatı, $\boldsymbol{\beta}_{\mathbf{0}}=$ Bireysel karakteristiklerle açıklanamayan fiyatı gösteren sabit, $\boldsymbol{\beta}_{\mathbf{1}}=$ Bireysel karakteristik katsayısı, $\mathbf{x}_{\mathbf{i}}=$ İşlem ile alakalı bireysel varlık karakteristiği, $\boldsymbol{\epsilon}=$ Rastgele hata

\subsubsection{Finansal Çarpanlar Marka Değerleme Modeli}

Diğer bir adı da mali oranlara dayalı marka değerleme modelidir. Mali oranlara dayalı olarak yapılan değerlemelere en güzel örneklerden biri, 2001 yılında yapılan bir çalışmada ayrıntılı olarak incelenen Aswath Damadoran (1994) tarafından Coca - Cola ve Kellogg markaları hakkında yapılan marka değerinin tespitine yönelik yapılan çalışmadır. Bu çalışmada marka değerleri, değerlenen markaya sahip olan işletme ile güçsüz bir markaya sahip işletmenin fiyat / satış oranları arasındaki farka göre 
hesaplanmıştır. Damodaran, Kellogg markasını 1994 yılı için 15,027 milyar dolar Coca - Cola markasını ise 1993 yılı için 24,579 milyar dolar, 1998 y1lı 102,642 milyar dolar olarak değerlemiştir (Fenandez, 2001, 16).

\subsubsection{Hirose Modeli}

Model, (Japonya Ekonomi, Ticaret ve Endüstri Bakanlığı'nca önerilen model) literatürde Japon Modeli olarak da adlandırılmaktadır. Bu model, 24 Haziran 2002 yılında Japonya Ekonomi Ticaret ve Endüstri Bakanlığg'nın organizasyonu ile Dr. Yoshikuni Hirose' nin başkanlığında yürütülen bir komisyon ile hazırlanmıştır (The Ministry of Economy, Trade and Industry The Government of Japan, 2001) . Bu modelin oluşturulmasında iki temel amaç vardır. Bunlar; (Beccacece, vd., 2002: 4)

- IIlk amaç; işletmelerin yıllık faaliyet raporlarından elde edilen finansal verilerin kullanılmasıyla daha objektif bir şekilde marka değerinin hesaplanabilmesidir.

- İkincisi ise; modelin markalar dışındaki diğer maddi olmayan duran varlıkların değerlemesine de kolaylıkla uygulanabilir hale getirilmesidir.

\section{BANKACILIK SEKTÖRÜNDE MARKA DEĞERLEME MODELLERININ BAHP YÖNTEMI İLE TESPIT EDILMESİ}

$\mathrm{Bu}$ bölümde bankacılık sektörüne uygulanabilecek olan finansal marka değerleme modelleri, uzman görüşleri ve literatür taramaları sonucunda belirlenen kriterler kapsamında karşılıklı olarak incelenmiştir.

\subsection{Türkiye'de Bankacılık Sektörüne Genel Bir Bakış}

Türkiye'de bankacılık sektörü, 2017 yılı Ocak ayı itibariyle 47 banka 10.696 yurt içi, 80 yurtdışı şube ile faaliyet göstermektedir. Türkiye' de faaliyet gösteren bankaların türleri ve sayıları Tablo 1.' de verilmiştir;

Tablo 1 . Türkiye’ de Faaliyet Gösteren Bankaların Türleri ve Sayıları

\begin{tabular}{|l|l|l|l|}
\hline \multicolumn{2}{|c|}{ Kamu Kalkınma ve Yatırım Bankaları } & & A.Ş. \\
\hline & İller Bankası & \multicolumn{2}{|l|}{} \\
\hline & Türkiye Kalkınma Bankası A.Ş. & \\
\hline & TMSF Bünyesindeki Bankalar & \\
\hline & Birleşik Fon Bankası Kredi Bankası \\
\hline & Özel Yatırım bankaları & & \multicolumn{2}{|c|}{ Diler yatırım bankası A.Ş. } \\
\hline & Aktif yatırım bankası A.Ş. & & Bankası Takas ve Saklama \\
\hline & GSD Yatırım Bankası A.Ş. & 1 & A.Ş. Türkiye Sınai Kalkınma Bankası \\
\hline
\end{tabular}




\begin{tabular}{|c|c|c|c|}
\hline \multicolumn{4}{|c|}{ Türkiye'de Kurulu Yabancı Yatırım Bankaları } \\
\hline 2 & $\begin{array}{ll}\text { Aş. } & \text { BankPozitif Kredi ve Kalkınma Bankası } \\
\end{array}$ & 3 & Merrill Lynch Yatırım Bank A.Ş. \\
\hline 4 & $\begin{array}{l}\text { Standart Chartered Yatırım Bankası Türk } \\
\text { A.Ş. }\end{array}$ & 5 & Pasha Yatırım Bankası A.Ş. \\
\hline \multicolumn{4}{|c|}{ Kamu Mevduat Bankaları } \\
\hline 6 & T.C. Ziraat Bankası & 7 & Türkiye Halk Bankası \\
\hline 8 & Türkiye Vakıflar Bankası & & \\
\hline \multicolumn{4}{|c|}{ Özel Mevduat Bankaları } \\
\hline 9 & Akbank T.A.Ş. & 0 & Anadolubank A.Ş. \\
\hline 1 & Fibabanka A.Ş. & 2 & Şekerbank T.A.Ş. \\
\hline 3 & Adabank A.Ş. & 4 & Turkish Bank A.Ş. \\
\hline 5 & Türk Ekonomi Bankası A.Ş. & 6 & Türkiye İş Bankası A.Ş. \\
\hline 7 & Yapı ve Kredi Bankası A.Ş. & & \\
\hline \multicolumn{4}{|c|}{ Türkiye'de Kurulu Yabancı Mevduat Bankaları } \\
\hline 8 & Alternatifbank A.Ş. & 9 & Arap Türk Bankası A.Ş. \\
\hline 0 & $\begin{array}{ll}\text { A.Ş. } & \text { Bank Of Tokyo Mitsubishi UFJ Turkey } \\
\end{array}$ & 1 & ING Bank A.Ş. \\
\hline 2 & HSBC Bank A.Ş & 3 & Finansbank A.Ş. \\
\hline 4 & Burgan Bank A.Ş. & 5 & Deutsche Bank A.Ş. \\
\hline 6 & Citibank A.Ş. & 7 & Denizbank A.Ş. \\
\hline 8 & Odea Bank A.Ş & 9 & Turkland Bank A.Ş. \\
\hline 0 & Türkiye Garanti Bankası A.Ş & 1 & Rabobank A.Ş. \\
\hline 2 & ICBC Turkey Bank A.Ş. & & \\
\hline \multicolumn{4}{|c|}{ Mevduat Toplama Yetkisine Sahip Yabancı Banka Şubeleri } \\
\hline 2 & Bank Mellat & 3 & Habib Bank Limited \\
\hline 4 & JP Morgan Chase & 5 & Societe Generale S.A. \\
\hline 6 & The Royal Bank Of Scotland PLC. & 7 & Intesa Sanpaolo S.P.A \\
\hline
\end{tabular}

Kaynak: https://www.tbb.org.tr/modules/banka-bilgileri/banka sube bilgileri.asp,

Yukarıda bahsi geçen bankaların, içinde faaliyet gösterdiği bankacılık sektörünün, aktif büyüklüğü 2.702.172 TL' dir. Bu aktif büyüklükten en çok payı alan mevduat bankalarıdır. Türk bankacılık sektöründe mevduat bankalarının payı \%80 civarındadir.

\subsection{Araştırmanın Metodolojisi}

Bu başlık altında araştırmanın, amacı, kısıtları, araştırmada kullanılacak modelin seçimi yer almaktadır. 


\subsubsection{Araștırmanın Amacı}

Türkiye'de ve Dünya'da marka değeriyle ilgili danışmanlık firmaları dışında yapılan çalışmalar genelde tüketici tabanlı olmaktadır. Ancak marka değerinin muhasebe ve finansal açıdan bir anlam ifade edebilmesi için finansal tablolardan elde edilen verilerle denetlenebilir, raporlanabilir modellerle ölçümünün yapılması gerekmektedir. $\mathrm{Bu}$ yüzden çalışmada finansal modeller kullanılmıştır. Ayrıca bu modeller arasından rastgele bir seçim yapılmamış çok kriterli karar verme modellerinden biri olan BAHP kullanılmıştır. Burada amaç, marka değerleme ile ilgili en çok karşılaşılan sorunlardan biri olan hangi modelin kullanılması gerektiği sorusuna cevap bulmaktır. Burada belirtmek gerekir ki amaç, en iyi modeli seçmekten ziyade uzmanlarla birlikte belirlenen ortak değerler çerçevesinde modellerin kıyaslanması ve ortak bir model belirlemeye yardımcı olmaktır. Konuyla ilgili, Uluslararası Değerleme Standartları Komitesi aşağıdaki ifadelerde bulunarak marka değerleme için ortak bir yol haritası çizilmesi gerekliliğini vurgulamıştır;

““.....Muhasebe standartlarının tüm dünyada ortak kabulü ile ortak bir uluslararası değerlendirme standardına olan ihtiyaç gittikçe kendini hissettirmektedir. Çıkış noktası olarak, IFRS'de yer alan "adil değer" tanımı kabul edilmektedir. Mevcut Uluslararası Değerlendirme Standartları 2000 yılından beri fiziki olmayan varlıkların değerlendirilmesine rehberlik edecek bilgiyi içermekteyken, IFRS'nin faaliyetlerin birleştirilmesi kavramını sunması ile bu konu daha önem kazanmıştır. 2006 yılında, IVSC, uzmanlardan oluşan bir ekibi IFRS raporlama gereklerine uygun değerlendirme çalışmalarına rehberlik edecek esasları tespit etmek üzere görevlendirmiştir. " (Gödren, 2010: 92)

Yapılan literatür taramaları sonrasında bankacılık sektöründe marka değerlemeye yönelik çalışmaların çok az sayıda olduğu görülmüştür ve bu boşluğun doldurulması amaçlanmıştır.

\subsubsection{Araștırmanın Kısıtları}

Bankaların marka değerlerinin hesaplarken kullanılacak olan modellerin tespiti ve BAHP yönteminin uygulanabilmesi için 7 marka değerleme uzmanı ve 7 akademisyenin görüşleri alınmıştır. $\mathrm{Bu}$ uzmanlara marka değerleme modellerinin birbirlerine göre kıyaslayabilmeleri için anket uygulanmıştır. BAHP yöntemiyle karşılaştırılan modeller piyasada en çok kullanılan finansal modellerle sınırlandırılmıştır. BAHP uygulamasında 9 adet finansal model kullanılmıştır. Bunun sebebi uygulamanın mali sektörde olması nedeniyle tüm modellerin mali sektöre göre 
revize edilememesi ve bazı modellerin birbirlerine çok benzemesidir. Parasal bir değer hesaplamaya yönelik olmaması nedeniyle davranışsal modeller, modellerin danışmalık firmaları tarafından geliştirilmiş olması ve bu firmaların hesaplamalara dair tüm bilgileri kamuoyuyla paylaşmamaları nedeniyle de karma modelleri çalışmaya dahil edilmemiştir.

\subsubsection{Araştırma Modelinin Seçimi}

Marka değerleme modellerin her birinin birbirinden farklı sonuçlar vermesi sorununu ortadan kaldırabilmek için araştırmada kullanılacak modellerin seçiminde çok kriterli bir karar verme yöntemi olarak bilinen "Analitik Hiyerarşi Prosesi” (AHP) yönteminin bulanık versiyonu kullanılmıştır.

Bulanık Analitik Hiyerarşi Prosesi; gerçek hayatta birçok karar verme probleminin çözümünde etkin bir biçimde kullanılan AHP yöntemi, ikili karşılaştırmalar sürecinde gerçek sayıların kullanılması açısından birçok eleştiriye maruz kalmıştır. Karar verici, sayısal tahminler yapma konusunda başarısızdır ancak niteliksel tahminlemelerde sayısal tahminlemelere göre daha etkindir (Kulak ve Kahraman, 2005: 192) . Bu nedenlerden dolayı BAHP yöntemi önerilmektedir. Yöntemde, kesin değerlerin kullanıldığı AHP'den farklı olarak kıyaslama oranları bir değer aralığında verilmektedir. Böylece karar verme sürecindeki belirsizliğin daha kolay üstesinden gelinebilmektedir (Paksoy, vd., 2013: 122).

BAHP'nin, literatürde çeşitli araştırmalar tarafından geliştirilmiş ve önerilen birçok yöntem mevcut olmasına rağmen en yaygın olarak kullanılan, bulanık üçgensel sayıları kullanarak hesaplama yapan ve Chang (1996) tarafindan önerilen Genişletilmiş Analiz Yöntemidir. Araştırma konusu olan bankacılık sektöründe marka değerleme modellerinin seçiminde bu yöntem kullanılmıştır.

BAHP yönteminde, karar kriterlerinin ve alternatiflerin değerlendirilmesinde kullanılan çeşitli araştırmacılar tarafından önerilen dilsel değerler ve üçgen bulanık sayı karşılıkları Tablo 2'de gösterilmiştir.

Tablo 2. Alternatiflerin Değerlendirilmesinde Kullanılan Dilsel Değerler ve Üçgensel Bulanık Sayı Karşılıkları

\begin{tabular}{|l|l|c|c|}
\hline \multicolumn{1}{|c|}{ Sözel Önem } & \multicolumn{1}{|c|}{ Matris İfadesi } & Bulanık Ölçek & $\begin{array}{l}\text { Karşılıklı } \\
\text { Ölçek }\end{array}$ \\
\hline Eşit derecede önemli & $\begin{array}{l}\text { İki faaliyet amaca eşit şekilde katkıda } \\
\text { bulunur }\end{array}$ & $(1,1,1)$ & $(1 / 1,1 / 1,1 / 1)$ \\
\hline Orta Derecede Önem & $\begin{array}{l}\text { Tecrübe ve yargı bir faaliyeti diğerine çok } \\
\text { az derecede tercih ettirir. }\end{array}$ & $(1,3,5)$ & $(1 / 5,1 / 3,1 / 1)$ \\
\hline $\begin{array}{l}\text { Kuvvetli Derecede } \\
\text { Önemli }\end{array}$ & $\begin{array}{l}\text { Tecrübe ve yargı bir faaliyeti diğerine } \\
\text { kuvvetli derecede tercih ettirir. }\end{array}$ & $(3,5,7)$ & $(1 / 7,1 / 5,1 / 3)$ \\
\hline $\begin{array}{l}\text { Çok Kuvvetli Derecede } \\
\text { Önemli }\end{array}$ & $\begin{array}{l}\text { Bir faaliyet güçlü bir şekilde tercih edilir ve } \\
\text { baskınlığ uygulamada rahatlıkla görülür }\end{array}$ & $(5,7,9)$ & $(1 / 9,1 / 7,1 / 5)$ \\
\hline $\begin{array}{l}\text { Mutlak Dërecede } \\
\text { Önemli }\end{array}$ & $\begin{array}{l}\text { Bir faaliyetin diğer bir faaliyete tercih } \\
\text { edilmesindeki kanıtlar mutlak güvenilirliğe } \\
\text { sahiptir. }\end{array}$ & $(7,9,9)$ & $(1 / 9,1 / 9,1 / 7)$ \\
\hline & \multicolumn{1}{|l}{} & \\
\hline
\end{tabular}




\begin{tabular}{|l|l|l|l|}
\hline Ara Değerler & & $(1,2,3)$ & $(1 / 3,1 / 2,1)$ \\
& & $(3,4,5)$ & $(1 / 5,1 / 4.1 / 3)$ \\
& & $(5,6,7)$ & $(1 / 7,1 / 6,1 / 5)$ \\
& & $(7,8,9)$ & $(1 / 9,1 / 8,1 / 7)$ \\
\hline
\end{tabular}

Kaynak: Turan Paksoy, Nimet Yapıcı Pehlivan, Eren Özceylan, “ Bulanık Küme Teorisi”, Nobel Yayın, Ankara, 2013, s. 126.

\subsection{Bankacılık Sektöründe Marka Değerleme Modellerinin BAHP ile Değerlendirmesi}

Araştırmanın temel amac1, bankacılık sektöründe kullanılabilecek finansal marka değerleme modellerinin BAHP ile karşılaştırmalı olarak analiz edilerek marka değerleme modellerinden göreceli olarak en optimum modele ulaşmaktır. Bu bağlamda, BAHP yöntemiyle uzman görüşleri ve literatür taramaları sonucunda belirlenen finansal marka değerleme modelleri arasında bir sıralama yapılmıştır. BAHP'nin uygulama adımları aşağıdaki açıklanmıştır.

\section{Aşama: Hiyerarşik Yapının Oluşturulması}

Marka değerleme konusunda uzman marka yöneticileri ve marka değerleme konusunda akademik çalışmalar yürüten akademisyenlerle birlikte ISO standartları da göz önünde bulundurularak hem değerlendirme kriterleri hem de marka değerleme modelleri (alternatifler) belirlenmiştir. Böylece ele alınan problem çerçevesinde belirlenen alternatiflere ve kriterlere ilişkin hiyerarşik yapı Şekil 1'deki gibi oluşturulmuştur. Şekil 1'de de görüleceği üzere; TMMDM: Tarihi Maliyet Marka Değerleme Modeli, İMMDM: İkame Maliyete Marka Değerleme Modeli, PDDMDM: Piyasa Değerine Dayalı Marka Değerleme Modeli, S\&S MDM: Simon \& Sulivan Marka Değerleme Modeli, FPMDM: Fiyat Primi Marka Değerleme Modeli, RKMDM: Royaltilerden Kurtulma Marka Değerleme Modeli, HMDM: Hedonik Marka Değerleme Modeli, FÇMDM: Finansal Çarpanlar Marka Değerleme Modeli, HİMDM: Hirose Marka Değerleme Modeli. Aşağıdaki Şekil 1'e göre;

İşlevsel Kriterler: Kendi içinde beş alt kritere ayrılmıştır. Bu kriterler; Modelin, pratikte uygulanıp uygulanmadığını ölçen Uygulanabilirlik, modelde kullanılan değişkenlerin ve bütün olarak modelin yapısının objektif olup olmadığını ölçen Objektiflik, modellerde kullanılacak olan bilgilere kolaylıkla ulaşılıp ulaşılmadığını ölçen Verilere Ulaşım Kolaylı̆̆l, modelin, marka değerini hesaplarken ne kadar çeşitli değişken kullandığını ölçen Hesaplamada Kullanılan Değişken Kapsamı, modelin teknik, istatistiki veya ekonometrik açıdan karmaşıklığını dolayısıyla kurulurken kolaylıkla kurulup kurulmadığını ölçen Kurulum Kolaylığ kriterleridir. 
Teknik Kriterler: Kendi içinde altı kritere ayrılmıştır. Bu kriterler; Gelecek Tahmini: Model tarafından gelecek tahmini yapılmakta mıdır?, Rakiplerle Klyas: Hem modelin verdiği sonuç rakiplerle karşılaştırılabilir midir?, hem de model marka değerini hesaplarken rakip işletmelerin bilgilerini de göz önünde bulundurmakta mıdır?, Finansal Analiz: Model de kullanılan değişkenler bir finansal analiz yapılarak mı elde edilmiştir, modelde finansal veriler analiz edilmektedir, modelin verdiği sonuç finansal analize konu olabilmekte midir?, Uluslararası Etkinlik: Firmanın uluslararası faaliyetleri göz önünde bulundurulmakta mıdır?, Pazarlama Faaliyetleri: Bilindiği üzere marka ile ilgili oluşturma ve geliştirme faaliyetleri pazarlama faaliyetleri içerisinde yer almaktadır. Model pazarlama faaliyetlerini sonuca ulaşırken göz önünde bulundurmakta midir?, Yasal Koruma: Markalar yasal olarak koruma altına alınabilmektedir ve bu bir maliyet unsurudur. Model yasal faaliyetlerle ilgili maliyetleri dikkate almakta midır? 


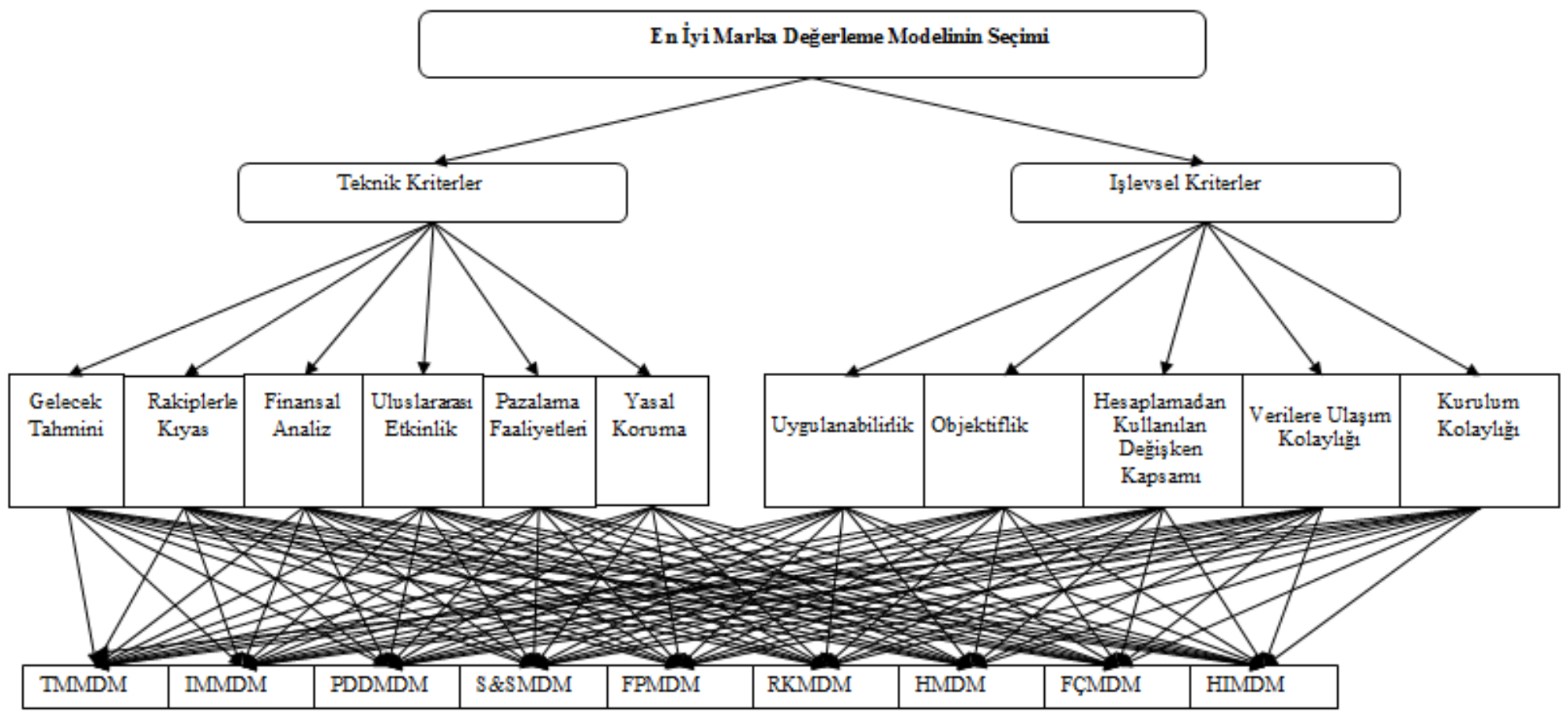

Șekil 1. Marka Değerleme Modelinin Belirlenmesinde Kullanılan Hiyerarşik Yapı 
2. Aşama: İkili Karşılaştırma Matrislerinin Oluşturulması ve Kriter Ağırlıklarının Hesaplanması

Ağırlıkların belirlenmesinde ilk aşama her bir kriterin hiyerarşik yapıya göre kendi seviyesindeki diğer kriterlerle karşılaştırılabilmesi için ikili karşılaştırma matrislerinin oluşturulmasıdır. Çalışmayla ilgili yedi uzmanın görüşleri alınmıştır. Uygulamada kullanılan bulanık önem dereceleri Tablo 3'te verilen değişkenlerdir. Tüm karşılaştırmalar dilsel değişkenler üzerinden yapılmıştır. Dilsel değişkenlere uygun anketler hazırlanmış ve uzmanlara bu anketler uygulanmıştır. Bu görüşler birleştirilerek aşağıdaki karşılaştırmalı matrislere ulaşılmıştır.

\section{- Ana Kriterlerin İkili Karşılaştırma Matrisi}

İşlevsel faktörler (IF) ve Teknik faktörlerin (TF), eşit derecede önemli olduğu yapılan anketler sonucunda görülmüş ve Matris 1 oluşturulmuştur.

Tablo 3. Ana Kriterlerin Bulanık Değerlendirme Matrisi

\begin{tabular}{|l|l|l|}
\hline & \multicolumn{1}{|c|}{ İşlevsel Kriterler } & \multicolumn{1}{c|}{ Teknik Kriterler } \\
\hline İşlevsel Kriterler & $(1,1,1)$ & $(1,1,1)$ \\
\hline Teknik Kriterler & $(1,1,1)$ & $(1,1,1)$ \\
\hline
\end{tabular}

1. Adım: Bulanık değerlendirme matrisinden ikili karşılaştırmanın sentetik boyut değerleri aşağıdaki gibi elde edilmiştir;

Matris 1 kullanılarak ölçütlere göre bulanık büyüklük değerleri bulunmuştur;

$\mathbf{S}_{\mathbf{i F}}=(2,2,2) \times(1 / 4,1 / 4,1 / 4)=(0.50,0.50,0.50)$

$\mathbf{S}_{\mathbf{T F}=(2,2,2) \times(1 / 4,1 / 4,1 / 4)=(0.50,0.50,0.50)}$

2. Adım: Bulanık büyüklük değerlerine göre olabilirlik dereceleri hesaplanmış ve ağırlık vektörü elde edilmiştir:

$$
\begin{aligned}
& V\left(S_{\mathbf{I F}_{\mathrm{F}}} \geq S_{\mathrm{TF}}\right)=\mathbf{1} \\
& \mathrm{V}\left(\mathrm{S}_{\mathrm{IF}} \geq S_{\mathrm{TF}}\right)=\mathbf{1}
\end{aligned}
$$

3. Adım: Ağırlık vektörü kullanılarak normalize edilmiş ağırlık vektörü bulunmuştur. Böylece söz konusu iki faktöre ilişkin göreli ağırlıklar elde edilerek aşağıda gösterilmiştir;

$$
W=\left[\frac{1 / 2}{1 / 2}\right]=\left[\frac{0,5}{0,5}\right]
$$

Elde edilen sonuçlar, faktörlerin birbirlerine göre eşit derecede önemli olmasından ötürü, her iki faktörün de 50\% ağırlığa sahip olduğu gösterilmiştir. 


\section{- Alt Kriterlerin İkili Karşılaştırma Matrislerinin Oluşturulması}

İşlevsel özellikler ve teknik özellikler ana kriterlerine ait alt kriterler için ikili karşılaştırma matrisleri oluşturulmuş ve uzman görüşleri doğrultusunda ikili çiftler halinde karşılaş̧tırılmış ve göreli ağırlıkları hesaplanmıştır.

\section{İşlevsel Özellikler Ana Kriterine Ait Alt Kriterler İçin İkili Karşılaştırma}

Matrisi: İşlevsel özellikler ana kriterinin alt kriterleri olan uygulanabilirlik, objektiflik, verilerin ulaşılabilirliği, hesaplamada kullanılan değişken kapsamı, kurulum kolaylığı kendi aralarında ikili karşılaştırılarak matris oluşturulmuştur.

Tablo 4. İşlevsel Özellikler Ana Kriterine Ait Alt Kriterlerin İkili Karşılaştırma Matrisi

\begin{tabular}{|l|l|l|l|l|l|}
\hline İşlevsel Kriterler & Uygulanabilirlik & Objektiflik & $\begin{array}{l}\text { Verilerin } \\
\text { Ulaşılabilirliği }\end{array}$ & $\begin{array}{l}\text { Hesaplamada } \\
\text { Kullanılan Değişken } \\
\text { Kapsamı }\end{array}$ & $\begin{array}{l}\text { Kurulum } \\
\text { Kolaylığı }\end{array}$ \\
\hline Uygulanabilirlik & $(1,1,1)$ & $3,4,5$ & $1,3,5$ & $3,5,7$ & $(7,9,9)$ \\
\hline Objektiflik & $1 / 5,1 / 4,1 / 3$ & $(1,1,1)$ & $1 / 5,1 / 3,1$ & $1,3,5$ & $5,6,7$ \\
\hline $\begin{array}{l}\text { Verilerin } \\
\text { Ulaşılabilirliği }\end{array}$ & $1 / 5,1 / 3,1$ & $1,3,5$ & $(1,1,1)$ & $3,4,5$ & $5,7,9$ \\
\hline $\begin{array}{l}\text { Hesaplamada } \\
\text { Kullanılan Değişsen } \\
\text { Kapsamı }\end{array}$ & $1 / 7,1 / 5,1 / 3$ & $1 / 5,1 / 3,1$ & $1 / 5,1 / 4,1 / 3$ & $1,1,1$ & $3,5,7$ \\
\hline Kurulum Kolaylığı & $1 / 9,1 / 9,1 / 7$ & $1 / 7,1 / 6,1 / 5$ & $1 / 9,1 / 7,1 / 5$ & $1 / 5,1 / 4,1 / 3$ & $(1,1,1)$ \\
\hline
\end{tabular}

1. Adım: Bulanık değerlendirme matrisinden ikili karşılaş̧ırmanın sentetik boyut değerleri aşağıdaki gibi elde edilmiş̧ir; Matris 2 kullanılarak ölçütlere göre bulanık büyüklük değerleri hesaplanmıştır.

$$
\begin{aligned}
\mathbf{S}_{\text {uyg }} & =(15 ; 22 ; 27)^{*}(0,01353616 ; 0,01773973 ; 0,025834) \\
& =(0,203042 ; 0,390274 ; 0,697531) \\
\mathbf{S}_{\text {obj }} & =(7,4 ; 10,5833 ; 21) *(0,01353616 ; 0,01773973 ; 0,025834) \\
& =(0,100168 ; 0,187746 ; 0,370294) \\
\mathbf{S}_{\text {veruls }} & =(10,2 ; 15,33333 ; 21) *(0,01353616 ; 0,01773973 ; 0,025834) \\
& =(0,138069 ; 0,272009 ; 0,542524) \\
\mathbf{S}_{\text {değ.kap }} & =(4,54286 ; 6,78333 ; 9,66667)^{*}(0,01353616 ; 0,01773973 ; 0,025834) \\
& =(0,061493 ; 0,120335 ; 0,249733) \\
\mathbf{S}_{\text {kur.kol. }} & =(1,56508 ; 1,67063 ; 1,87619) *(0,01353616 ; 0,01773973 ; 0,025834) \\
& =(0,021185 ; 0,029637 ; 0,04847)
\end{aligned}
$$


2. Adım: Bulanık büyüklük değerlerine göre olabilirlik dereceleri hesaplanmış ve ağırlık vektörü elde edilmiştir:

Tablo 5. Bulanık Büyüklük Değerlerine Göre Olabilirlik Dereceleri

\begin{tabular}{|c|c|c|}
\hline \multirow{2}{*}{ Uygulama Kriteri } & $\mathrm{V}\left(\mathrm{S}_{\mathrm{UYG}} \geq \mathrm{S}_{\text {OBJ }}\right)=\mathbf{1}$ & $V\left(S_{\text {UYG }} \geq S_{\text {VERULS }}\right)=1$ \\
\hline & $V\left(S_{U Y G} \geq S_{\text {DEĞ.KAP }}\right)=1$ & $V\left(S_{U Y G} \geq S_{\text {KUR.KOL. }}\right)=1$ \\
\hline \multirow{2}{*}{ Objektiflik Kriteri } & $\mathrm{V}\left(\mathrm{S}_{\mathrm{OBJ}} \geq \mathrm{S}_{\mathrm{UYG}}\right)=\mathbf{0 , 4 5 2 3 0 1}$ & $V\left(S_{\text {OBJ }} \geq S_{\text {VERULSS }}\right)=\mathbf{0 , 7 3 3 7 5}$ \\
\hline & $V\left(S_{\text {OBJ }} \geq S_{\text {DEĞ.KAP }}\right)=1$ & $V\left(S_{\text {OBJ }} \geq S_{\text {KUR.KOL. }}\right)=1$ \\
\hline \multirow{2}{*}{ Verilerin Ulaşılabilirliği } & $V\left(S_{\text {VERULS S }} \geq S_{\text {UYG }}\right)=0,741637$ & $V\left(S_{\text {VERULS }} \geq S_{\text {OBJ }}\right)=1$ \\
\hline & $V\left(S_{\text {VERULŞ }} \geq S_{\text {DEĞ.KAP }}\right)=1$ & $V\left(S_{\text {VERULŞ }} \geq S_{\text {KUR.KOL. }}\right)=1$ \\
\hline \multirow{2}{*}{$\begin{array}{l}\text { Hesaplamada Kullanılan } \\
\text { Değişken Kapsamı }\end{array}$} & $V\left(S_{\text {DEĞ.KAP }} \geq S_{\text {UYG }}\right)=0,147462$ & $V\left(S_{\text {DEĞ.KAP }} \geq S_{\text {OBJ }}\right)=0,689317$ \\
\hline & $V\left(S_{\text {DEĞ.KAP }} \geq S_{\text {VERULŞ })}=\mathbf{0 , 4 2 4 0 3 3}\right.$ & $V\left(S_{\text {DEĞ.KAP }} \geq S_{\text {KUR.KOL. }}\right)=1$ \\
\hline \multirow{2}{*}{ Kurulum Kolaylığı } & $\mathbf{V}\left(\mathbf{S}_{\text {KUR.KOL. }} \geq \mathbf{S}_{\text {UYG }}\right)=\mathbf{0}$ & $\mathbf{V}\left(\mathbf{S}_{\mathrm{KUR} . \mathrm{KOL}} \geq \mathbf{S}_{\mathrm{OBJ}}\right)=\mathbf{0}$ \\
\hline & $V\left(S_{\text {KUR.KOL }} \geq S_{\text {DEĞ.KAP }}\right)=0$ & $\mathbf{V}\left(\mathbf{S}_{\mathrm{KUR} . \mathrm{KOL}} \geq \mathbf{S}_{\text {VERULS })=} \mathbf{0}\right.$ \\
\hline
\end{tabular}

3. Adım: Her bir karşılaştırma matrisinde yer alan minumum değerler alınır.

Min = \begin{tabular}{|l|l|l|l|l|}
\hline 1,0000 & $\mathbf{0 , 4 5 2 3 0 1}$ & $\mathbf{0 , 7 4 1 6 3 7}$ & $\mathbf{0 , 1 4 7 4 6 2}$ & $\mathbf{0 , 0 0 0 0 0}$ \\
\hline
\end{tabular}

4. Adım: Ağırlık vektörü kullanılarak normalize edilmiş ağırlık vektörü bulunmuştur. Böylece söz konusu beş faktöre ilişkin hesaplanan göreli ağırlıklar Tablo 5' de gösterilmiştir;

Tablo 6. İşlevsel Özellikler Ana Kriterine Ait Alt Kriterlerin Hesaplanan Göreli Ağırlıkları

\begin{tabular}{|l|c|}
\hline \multicolumn{1}{|c|}{ İşlevsel Kriterleri } & Ağırlık Vektörleri \\
\hline Uygulanabilirlik & 0,42709 \\
\hline Objektiflik & 0,19317 \\
\hline Verilerin Ulaşılabilirliği & 0,31675 \\
\hline Hesaplamada Kullanılan Değişken Kapsamı & 0,06299 \\
\hline Kurulum Kolaylığı & 0 \\
\hline \multicolumn{1}{|c|}{ Bundan sonraki aşamalarda hesaplama adimları birebir benzerlik }
\end{tabular}
göstermektedir, bu yüzden diğer kriterler bakımından göreli ağırlıkları model tespiti adımında toplu olarak verilmiştir.

Teknik Özellikler Ana Kriterine Ait Alt Kriterler İçin İkili Karşılaştırma Matrisi: Teknik kriterlere ait BAHP hesaplamaları ve hesaplama adımları işlevsel kriterleri aynı olduğu için örnek olarak ana kriterin alt kriterlere gmre hesaplanan göreli 
ağırlıkları Tablo 6'da verilmiş, her bir alternatifin teknik kriterlerden aldığı puanlar ise model seçimi aşamasında toplu olarak gösterilmiştir.

Tablo 7.Teknik Özellikler Ana Kriterine Ait Alt Kriterlerin Hesaplanan Göreli Ağırlıkları

\begin{tabular}{|l|c|}
\hline \multicolumn{1}{|c|}{ Teknik Kriterleri } & Ă̆ırlık Vektörleri \\
\hline Gelecek Tahmini & 0,34872 \\
\hline Rakiplerle Kiyas & 0,21151 \\
\hline Finansal Analiz & 0,28625 \\
\hline Uluslararası Etkinlik & 0,03628 \\
\hline Pazarlama Faaliyetleri & 0,11724 \\
\hline Yasal Koruma $\quad$ Toplam & 0,00000 \\
\hline \multicolumn{2}{|c|}{} \\
\hline
\end{tabular}

\section{Aşama: Modellerin Tespit Edilmesi}

Son aşama karşılaştırma matrislerinden elde edilen ağırlık vektörlerinin birleştirilmesi aşamasıdır.

Tablo 8. İşlevsel Kriterlere Göre Ağırlık Vektörlerinin Kombinasyonu

\begin{tabular}{|c|c|c|c|c|c|}
\hline \multicolumn{6}{|c|}{ İŞLEVSEL KRİTERLER ; W = \%50 } \\
\hline & Uygulanabilirlik & Objektiflik & $\begin{array}{c}\text { Verilerin } \\
\text { Ulaşılabilirliği }\end{array}$ & $\begin{array}{l}\text { Hesaplamada } \\
\text { Kullanılan } \\
\text { Değişken } \\
\text { Kapsamı }\end{array}$ & $\begin{array}{l}\text { Kurulum } \\
\text { Kolaylığı }\end{array}$ \\
\hline AĞIRLIK & 0,42709 & 0,19317 & 0,31675 & 0,06299 & 0,00000 \\
\hline \multicolumn{6}{|c|}{ ALTERNATÍFLER } \\
\hline TMMDM & 0,13194 & 0,14878 & 0,1159 & 0,00000 & 0,11935 \\
\hline İMMDM & 0,00000 & 0,00000 & 0,05091 & 0,00000 & 0,00000 \\
\hline PDDMDM & 0,00000 & 0,03012 & 0,00000 & 0,08475 & 0,00000 \\
\hline S\&S MDM & 0,05042 & 0,17012 & 0,09949 & 0,18709 & 0,08576 \\
\hline FDMDM & 0,04776 & 0,00000 & 0,14124 & 0,15386 & 0,19171 \\
\hline RKMDM & 0,30634 & 0,00000 & 0,19311 & 0,14030 & 0,18115 \\
\hline HMDM & 0,00000 & 0,00000 & 0,00000 & 0,08998 & 0,00000 \\
\hline FÇMDM & 0,15721 & 0,32549 & 0,19881 & 0,17035 & 0,21085 \\
\hline HİMDM & 0,30634 & 0,32549 & 0,20055 & 0,17367 & 0,21085 \\
\hline
\end{tabular}

Tablo 9. Alternatiflerin İşlevsel Kriterlere Göre Aldıkları Toplam Puanlar

\begin{tabular}{|c|c|c|c|c|c|c|c|}
\hline \multicolumn{8}{|c|}{ İŞLEVSEL KRİTERLER ; W = \%50 } \\
\hline & Uygulanabilirlik & $\begin{array}{c}\text { Objektifli } \\
\mathbf{k}\end{array}$ & $\begin{array}{c}\text { Verilerin } \\
\text { Ulaşılabilirliği }\end{array}$ & $\begin{array}{l}\text { Hesaplamad } \\
\text { a Kullanılan } \\
\text { Değişken } \\
\text { Kapsamı } \\
\end{array}$ & $\begin{array}{l}\text { Kurulum } \\
\text { Kolaylığı }\end{array}$ & TOPLAM & $\% 50$ \\
\hline AĞIRLIK & 0,42709 & 0,19317 & 0,31675 & 0,06299 & 0,00000 & 0,42709 & 0,05 \\
\hline \multicolumn{8}{|c|}{ ALTERNATÍFLER } \\
\hline TMMDM & 0,0563506 & 0,028740 & 0,0367111 & 0,00000 & 0,00000 & 0,12180 & 0,06090 \\
\hline
\end{tabular}




\begin{tabular}{|l|c|c|c|c|c|c|c|}
\hline \hline & & 5 & & & & & \\
\hline İMMDM & 0,00000 & 0,00000 & 0,01613 & 0,00000 & 0,00000 & 0,01613 & 0,00806 \\
\hline PDDMDM & 0,00000 & 0,00582 & 0,00000 & 0,00534 & 0,00000 & 0,01116 & 0,00558 \\
\hline S\&S MDM & 0,02153 & 0,03286 & 0,03151 & 0,01178 & 0,00000 & 0,09769 & 0,04885 \\
\hline FDMDM & 0,02040 & 0,00000 & 0,04474 & 0,00969 & 0,00000 & 0,07483 & 0,03741 \\
\hline RKMDM & 0,13084 & 0,00000 & 0,06117 & 0,00884 & 0,00000 & 0,20084 & 0,10042 \\
\hline HMDM & 0,00000 & 0,00000 & 0,00000 & 0,00567 & 0,00000 & 0,00567 & 0,00283 \\
\hline FÇMDM & 0,06714 & 0,06288 & 0,06297 & 0,01073 & 0,00000 & 0,20372 & 0,10186 \\
\hline HİMDM & 0,13084 & 0,06288 & 0,06352 & 0,01094 & 0,00000 & 0,26816 & 0,13409 \\
\hline
\end{tabular}

Tablo 10.Teknik Kriterlere Göre Ağırlık Vektörlerinin Kombinasyonu

\begin{tabular}{|c|c|c|c|c|c|c|}
\hline \multicolumn{7}{|c|}{ TEKNIKK KRIITERLER ; W = \%50 } \\
\hline & $\begin{array}{c}\text { Gelecek } \\
\text { Tahmini }\end{array}$ & $\begin{array}{c}\text { Rakiplerle } \\
\text { Kıyas }\end{array}$ & $\begin{array}{c}\text { Finansal } \\
\text { Analiz }\end{array}$ & $\begin{array}{l}\text { Pazarlama } \\
\text { Faaliyetleri }\end{array}$ & $\begin{array}{c}\text { Uluslar Arası } \\
\text { Etkinlik }\end{array}$ & $\begin{array}{c}\text { Yasal } \\
\text { Koruma }\end{array}$ \\
\hline AĞIRLIK & 0,34872 & 0,21151 & 0,28625 & 0,03628 & 0,11724 & 0,00000 \\
\hline \multicolumn{7}{|c|}{ ALTERNATIFLER } \\
\hline TMMDM & 0,00000 & 0,00000 & 0,00000 & 0,09171 & 0,00000 & 0,22568 \\
\hline İMMDM & 0,00000 & 0,00000 & 0,00000 & 0,12989 & 0,00000 & 0,22568 \\
\hline PDDMDM & 0,00000 & 0,06989 & 0,07381 & 0,09904 & 0,00000 & 0,00000 \\
\hline S\&S MDM & 0,24025 & 0,11710 & 0,13305 & 0,21973 & 0,00000 & 0,27432 \\
\hline FDMDM & 0,37987 & 0,20579 & 0,15634 & 0,14818 & 0,00000 & 0,00000 \\
\hline RKMDM & 0,37988 & 0,11711 & 0,21758 & 0,00000 & 0,37329 & 0,27432 \\
\hline HMDM & 0,00000 & 0,00000 & 0,20961 & 0,09171 & 0,00000 & 0,00000 \\
\hline FÇMDM & 0,00000 & 0,17295 & 0,20961 & 0,00000 & 0,00000 & 0,00000 \\
\hline HİMDM & 0,00000 & 0,31716 & 0,00000 & 0,21974 & 0,62671 & 0,00000 \\
\hline
\end{tabular}

Tablo 11. Alternatiflerin Teknik Kriterlere Göre Aldıkları Toplam Puanlar

\begin{tabular}{|l|l|l|l|l|l|l|l|l|l|}
\hline & \multicolumn{9}{|c|}{ TEKNIK KRITERLER ; W= \%50 } \\
& $\begin{array}{c}\text { Gelecek } \\
\text { Tahmini }\end{array}$ & $\begin{array}{c}\text { Rakiplerle } \\
\text { Kiyas }\end{array}$ & $\begin{array}{c}\text { Finansal } \\
\text { Analiz }\end{array}$ & $\begin{array}{c}\text { Pazarlama } \\
\text { Faaliyetleri }\end{array}$ & $\begin{array}{c}\text { Uluslar } \\
\text { Arası } \\
\text { Etkinlik }\end{array}$ & $\begin{array}{c}\text { Yasal } \\
\text { Koruma }\end{array}$ & TOPLAM & \%50 \\
\hline AĞIRLIK & 0,34872 & 0,21151 & 0,28625 & 0,03628 & 0,11724 & 0,00000 & 1,00000 & 0,50 \\
\hline & \multicolumn{7}{|c|}{ ALTERNATIFLER } \\
\hline TMMDM & 0,00000 & 0,00000 & 0,00000 & 0,00333 & 0,00000 & 0,00000 & 0,00333 & 0,0016636 \\
\hline İMMM & 0,00000 & 0,00000 & 0,00000 & 0,00471 & 0,00000 & 0,00000 & 0,00471 & 0,0023562 \\
\hline PDDMDM & 0,00000 & 0,01478 & 0,02113 & 0,00359 & 0,00000 & 0,00000 & 0,03950 & 0,0197519 \\
\hline S\&S MDM & 0,08378 & 0,02477 & 0,03809 & 0,00797 & 0,00000 & 0,00000 & 0,15461 & 0,0773026 \\
\hline FDMDM & 0,13247 & 0,04353 & 0,04475 & 0,00538 & 0,06322 & 0,00000 & 0,22612 & 0,1130616 \\
\hline RKMDM & 0,13247 & 0,02477 & 0,06228 & 0,00000 & 0,00000 & 0,00000 & 0,26329 & 0,1316442 \\
\hline HMDM & 0,00000 & 0,00000 & 0,06000 & 0,00333 & 0,00000 & 0,00000 & 0,06333 & 0,0316641 \\
\hline FÇMDM & 0,00000 & 0,03658 & 0,06000 & 0,00000 & 0,10614 & 0,00000 & 0,09658 & 0,0482908 \\
\hline HİMDM & 0,00000 & 0,06708 & 0,00000 & 0,00797 & 0,00000 & 0,00000 & 0,14853 & 0,0742651 \\
\hline
\end{tabular}

Tablo 12. Ağırlık Vektörlerinin Birleştirilmesi Sonucu Elde Edilen Marka Değerleme Modellerinin Sıralaması

\begin{tabular}{|l|l|c|}
\hline \multicolumn{1}{|c|}{ Marka Değerleme Modelleri } & Sura no \\
\hline Tarihi Maliyet Marka Değerleme Modeli & 0,06256 & $\mathbf{6}$ \\
\hline İkame Maliyet Marka Değerleme Modeli & 0,01042 & $\mathbf{9}$ \\
\hline Piyasa Değerine Dayalı Marka Değerleme Modeli & 0,02533 & $\mathbf{7}$ \\
\hline Simon \& Sulivan Marka Değerleme Modeli & 0,12615 & $\mathbf{5}$ \\
\hline Fiyat Primine Dayalı Marka Değerleme Modeli & 0,15047 & $\mathbf{3}$ \\
\hline
\end{tabular}




\begin{tabular}{|l|l|c|}
\hline Royaltilerden Kurtulma Marka Değerleme Modeli & 0,23206 & $\mathbf{1}$ \\
\hline Hedonik Marka Değerleme Modeli & 0,03449 & $\mathbf{8}$ \\
\hline Finansal Çarpanlarla Marka Değerleme Modeli & 0,15015 & $\mathbf{4}$ \\
\hline Hiroshi Marka Değerleme Modeli & 0,20836 & $\mathbf{2}$ \\
\hline
\end{tabular}

BAHP yöntemiyle yapılan analizler sonucunda belirlenen kriterler altında marka değerleme modelleri içerisinden "royaltilerden kurtulma modeli" birinci sirayı alırken ikinci sırayı "hiroshi modeli" almıştır. Bu iki model bankacılık sektörüne uygun olacak şekilde revize edilerek bir sonraki çalışmamızda uygulanacaktır.

\section{SONUÇ}

Marka değerinin ölçülmesi ihtiyacı finansal modeller, tüketici ve davranış temelli modeller, karma modeller gibi birçok marka değeri ölçüm modelinin ortaya çıkmasına sebep olmuştur. Bu modellerin her biri farklı bileşenleri içermekte ve farklı sonuçlar vermektedir. Marka değerlemedeki tartışmaların odak noktalarından bir tanesi bu modellerden hangisinin marka değerlemede kullanılacağı noktasında yoğunlaşmaktadır. Akademisyenler ve şirket yöneticileri modellerin marka değerlemede, subjektif unsurlar içermesi sebebiyle her modelin üstün yönleri olduğu gibi zayıf yönleri olduğunu ifade etmektedirler.

$\mathrm{Bu}$ noktada Uluslararası Değerleme Standartları Kurulu ve marka konusunda çalışmalar yapan uluslararası kurumlar, ortak bir marka değerleme modeli geliştirilmesi veya mevcut modellerden birinin belirlenmesinin ve standarda bağlanmasının önemini vurgulayan raporlar hazırlamakta ve yayınlamaktadırlar.

Araştırmada bu ortak modelin veya modellerin belirlenmesine yönelik olarak çok kriterli karar verme modellerinden biri olan BAHP yöntemi önerilmiştir. BAHP yöntemiyle yapılan analiz sonucunda herhangi bir marka değerleme modelinin sonuç olarak "en iyi" marka değerleme modeli olarak sunulması kesinlikle arz etmemektedir. "Sonlu seçenekli kapalı kısıtlı problemlerde en iyi çözüm diye bir şey söz konusu değildir. Çünkü çözüm, tamamen kişisel önceliklere ve kriterlere verilen öneme bağlı olarak bulunmaktadır. Bu nedenle herkes için en iyi olarak kabul edilecek bir seçenek söz konusu değildir.

BAHP yöntemiyle karşılaştırılan modeller finansal modellerle sınırlandırılmıştır. Modele davranışsal modellerin dahil edilmemesinin sebebi, davranışsal modellerin parasal bir değer hesaplamaya yönelik olmamasıdır. Karma modellerin dahil edilmemesinin sebebi ise bu modellerin danışmalık firmaları tarafından geliştirilmiş olması ve bu firmaların hesaplamalara dair tüm bilgileri kamuoyuyla 
paylaşmamalarıdır. İlerleyen zamanlarda bu firmaların bu bilgileri kamuoyuyla paylaşmaları durumunda BAHP yöntemiyle kurulan modele dahil edilebilmeleri mümkündür. $\mathrm{Bu}$ durumda sonuçlar yeniden değerlendirilebilir.

Araştırmada piyasa değerleri göz önüne alındığında ülkemizde en güçlü sektörlerden biri olan bankacılık sektörü ele alınmıştır. Bu sektörde uygulanabilecek modellerin belirlenebilmesi için, öncelikle marka değerleme konusunda uzman marka yöneticileri ve akademik çalışmalar yürüten akademisyenlerle birlikte bankaların finansal yapısı ve mali tabloları da göz önünde bulundurularak değerlendirme kriterleri belirlenmiştir. Bu noktada karşılaşılan en büyük problem Türkiye'de marka değerleme konusunda çalışan akademisyen ve marka değerleme uzmanlarının çok az sayıda olmasıdır. Konuyla ilgili çalışanların ise tüm marka değerleme modellerine vakıf olmamaları ise ayrı bir problem olarak karşımıza çıkmaktadır. Bu yüzden bu kriterlerin belirlenmesinde ve bir sonraki aşama olan değerlendirilmesinde Türkiye genelinde 14 uzman ve akademisyene ulaşılabilmiş ve konuyla ilgili görüşleri alınabilmiştir. Bu noktada değerleme kurullarının ve muhasebe alanında düzenleme yapma yetkisine sahip kuruluşların marka ve marka değerleme konusunda uzman kişilerle daha kapsamlı bir çalışma yürütmeleri yöntemin daha kapsamlı uygulanabilmesine imkan tanıyacaktır.

Çalışmada birlikte çalışılan akademisyen ve uzmanlarla birlikte marka değerleme modelleri analiz edilirken kullanılacak iki ana kriter belirlenmiştir. Bu ana kriterler; işlevsel kriterler ve teknik kriterlerdir. İşlevsel kriterlere ait alt kriterler; uygulanabilirlik, objektiflik, verilere ulaşım kolaylığı, hesaplamada kullanılan değişken kapsamı ve kurulum kolaylığıdır. Teknik kriterler ise; gelecek tahmini, rakiplerle kıyas, finansal analiz, uluslararası etkinlik, pazarlama faaliyetleri ve yasal korumadir.

Kıyaslamanın yapılacağı alternatifler ise şu şekildedir; tarihi maliyet, ikame maliyet, piyasa değerine dayalı, Simon \& Sulivan, fiyat primi, royaltilerden kurtulma, hedonik, finansal çarpanlara dayalı ve hirose marka değerleme modellleridir.

$\mathrm{Bu}$ modellerin yukarıda bahsedilen kriterlerden aldıkları puanlar ve yapılan analiz sonucunda alternatifler arasındaki oluşan sıralamada 0,23206 ile royaltilerden kurtulma marka değerleme modeli ilk sirada yer alırken, bunu sirasıyla 0,20836 ile hiroshi marka değerleme modeli, 0.15047 ile fiyat primine dayalı marka değerleme modeli, 0,15015 ile finansal çarpanlar marka değerleme modeli, 0.12615 ile simon \& sulivan marka değerleme modeli, 0,06256 ile tarihi maliyet marka değerleme modeli, 0,03449 ile hedonik marka değerleme modeli, 0,02533 ile piyasa değerine dayalı marka değerleme modeli, 0,01042 ile ikame maliyet marka değerleme modeli takip etmiştir.

BAHP yöntemiyle yapılan analizler sonucunda belirlenen kriterler altında marka değerleme modelleri içerisinden Royaltilerden Kurtulma Modeli birinci sırayı alırken ikinci sırayı Hiroshi Modeli almıştır. Bu iki model bankacılık sektörüne uygun olacak şekilde revize edilerek bir başka çalışmamızda uygulanmış ve sonuçlar Dünyaca ünlü Brand Finance danışmanlık şirketinin yayınladığı marka değerleriyle karşılaştırılmıştır. 


\section{KAYNAKLAR}

Aaker, David. (1991), "Managing Brand Equity Capitilalizing on the Value of a Brand Name," The Free Press, New York.

Aaker, David. (1996), "Building Strong Brands," The Free Press, Macmillan Inc., New York, USA.

Baldinger, Alen. L. (1990). "Defining and Applying The Brand Equity Concept” Journal of Advertising Research, Vol. 3, No. 2, pp.76-88.

Beccacece, Francesca. Borgonovo, Emanuele. Reggiani, Francesco. (2002), "Risk Analysis in Brand Valuation", Bocconi University, pp. 1-21.

Calderón Haydeé, Cervera Amparo and Mollá Alejandro, (1997), "Brand Assessment: A Key Element of Marketing Strategy", Journal Of Product \& Brand Management, Vol. 6, No. 5, pp. 293-304.

Çelik, Arzum. (2006) "Marka Değerleme” Muhasebe ve Finansman Dergisi, Sayı 31, ss. $195-208$.

Da- Yong Chang, (1996), "Applications of the Extent Analysis Method on Fuzzy”, European Journal of Operational Research, Vol. 95, No. 3, pp. 649-655.

Damodaran, Aswath (1994), "Damodaran on Valuation", John Wiley and Sons, New York.

Deran, Ali. İskenderoğlu, Ömer. Hatipoğlu, Ayşe Gül. (2008) "Marka Değerinin Hesaplanmasında İzlenen Yaklaşımlar Ve Maddi Olmayan Bir Duran Varlık Unsuru Olarak Marka Değerinin Muhasebeleştirilmesi Sorunu" Selçuk Üniversitesi Sosyal Bilimler MYO Dergisi Vol. 10 No. 1-2, ss. 51-80.

Dutta, Sumanta ve Gupta, Raj D. (2011) "Challenges of Globalization Strategies for Competitiveness - Brand Valuation - A Contemporary Accounting Practices", Macmillan Publishers, India.

Duygu Frrat ve Cemkut Badem. (2008), “ Marka Değerleme Yöntemleri ve Marka Değerinin Mali Tablolara Yansitılması", Muhasebe ve Finansman Dergisi, Say1 38, ss. 210-218.

Farok J. Contractor. (2001), “ Valuation of Intengible Assets in Global Operations” USA.

Farquhar, Peter H. (1989), "Managing Brand Equity", Journal of Advertising Research, , Vol. 1, No. 3, pp, 24-33. 
Farquhar, Peter H. Han, Julia Y. Ijiri, Yuri. (1992), "Brands on The Balance Sheet", Marketing Management, Vol:1, No:1, pp. 16-22.

Feldwick, Poul. (1996), "What Is Brand Equity Anyway And How Do You Measure It?” Journal Of Market Research Society, Vol.38, No.2, pp. 85- 105.

Fernandez, Pablo. (2001), "Valuation of Brand Intellectual Capital", IESE University of Navarra, Research Paper, Madrid, Spain.

Gödren, Ferdi. (2010), “Marka Değerleme Yöntemleri ve AHP İle Uygun Modellerin Saptanması", Yüksek Lisan Tezi, Marmara Üniversitesi, Sosyal Bilimler Enstitüsü, Ekonometri Anabilim Dalı, İstanbul.

Haxthausen, Ove. (2009), “Valuing Brands and Brand Investments: Key Learnings and Future Expections", Brand Management, Vol.17, No.1, pp. 18-25.

Kaya, Yusuf. "Marka Değerlemelerinin Kullanım Alanları ve Örnek Marka Değerleme", http://www.istanbulpatent.com/mak_marka_degerlemeleri.pdf, (20/06/2013).

Keller, Kevin L. (1993), "Conceptualizing, Measuring, and Managing Customer-Based Brand Equity”, Journal of Marketing, Vol. 57, No. 1, pp. 1-22.

Keller, Kevin L. (2008), "Strategic Brand Management" 3th Edition, Prentice Hall International.

Konecnik, Maja ve Gartner, William C. (2007), "Customer-Based Brand Equity for a Destination”, Annals of Tourism Research, Vol. 34, No. 2, pp. 400-421.

Kulak, Osman ve Kahraman. Cengiz. (2005), "Fuzzy Multi-Attribute Selection Among Transportation Companies Using Axiomatic Design and Analytic Hierarchy Process", Information Sciences, Vol. 170, No. 2, pp. 191-210.

Motameni, Reza ve Shahrokhi, Manuchehr. (1998), "Brand Equity Valuation: A Global Perspective" Journal Of Product \& Brand Management, Vol. 7 No. 4, pp. 275290.

Paksoy, Turan. Yapıcı, Nimet. Pehlivan ve Eren Özceylan, (2013), "Bulanık Küme Teorisi", Nobel Yayınları, Ankara.

Simon, Carol J ve Sullivan, Mary W. (1993), "The Measurement and Determination of Brand Equity: A Financial Approach”, Marketing Science, Vol.12, No. 1, pp. 28-52.

Şoğur, Macide. (2012), “Marka” Derin Yayınları, İstanbul.

The Ministry of Economy, Trade and Industry The Government of Japan, (2002), "The Report of the Commitee on Brand Valuation", Japan.

Wyner, Gordon. (2004), "Where's the Value”, Marketing Management, Vol. 13, No. 3. Yüksel, Ülkü ve Yüksel-Mermod, Aslı. (2005), "Marka Yönetimi ve Marka Değerinin Ölçülmesi”, Beta Yayıncılık, İstanbul. 
Zimmermann, Rainer vd., (2001), "Brand Equity Excellence - Volume 6: Brand Valuation”, Published By BBDO, Germany.

556 Sayılı Markaların Korunması Hakkında KHK, Kararname Tarihi 24.06.1995, Resmi Gazete Tarihi / Say1s1: 27.06.1995/22326.

www.muhasebeturk.com.tr (21/12/2013).

https://www.tbb.org.tr/modules/banka-bilgileri/banka_sube_bilgileri.asp (05/02/2017) 